\title{
Assessment of groundwater quality status by using water quality index (WQI) and geographic information system (GIS) approaches: a case study of the Bokaro district, India
}

\author{
Poornima Verma ${ }^{1} \cdot$ Prasoon Kumar Singh ${ }^{1} \cdot$ Ritu Ranjan Sinha ${ }^{1} \cdot$ Ashwani Kumar Tiwari ${ }^{2}$
}

Received: 27 May 2016 / Accepted: 30 October 2019 / Published online: 5 December 2019

(c) The Author(s) 2019

\begin{abstract}
One hundred two groundwater samples were collected from the Bokaro district of Jharkhand state, India, during the pre-and post-monsoon seasons of the year 2014-2015. In the present study, groundwater samples were analysed for $\mathrm{pH}$, TDS, TH, $\mathrm{Ca}^{2+}, \mathrm{Mg}^{2+}, \mathrm{Na}^{+}, \mathrm{K}^{+}, \mathrm{Cl}^{-}, \mathrm{SO}_{4}{ }^{2-}, \mathrm{HCO}_{3}{ }^{-}, \mathrm{F}^{-}$and $\mathrm{NO}_{3}{ }^{-}$to evaluate the suitability of the groundwater for drinking purposes through geographic information system (GIS)-based water quality index (WQI) model. For quality assessment, values of analysed parameters of the groundwater samples were compared with the Bureau of Indian standards (BIS) and World Health Organization (WHO) water quality standards. The analytical results indicate slightly acidic to slightly alkaline nature of the groundwater in the study area. Concentrations of $\mathrm{Ca}^{2+}, \mathrm{Mg}^{2+}, \mathrm{HCO}_{3}^{-}, \mathrm{F}^{-}, \mathrm{NO}_{3}^{-}$, TDS and TH exceeded the desirable as well as permissible limits of drinking water quality standards recommended by the BIS (Indian Standard Drinking Water Specification, 2012) and WHO (Guidelines for drinking water quality: training pack, WHO, Geneva, 2004) in the study area during the pre- and post-monsoon seasons, respectively. However, $\mathrm{Na}^{+}, \mathrm{K}^{+}, \mathrm{Cl}^{-}$and $\mathrm{SO}_{4}{ }^{2-}$ concentrations were within the permissible limits during both seasons. The hydrochemical analysis of the studied groundwater samples documented with ternary and Durov diagram revealed that most of the groundwater samples belong to $\mathrm{HCO}_{3}{ }^{-}$type of anions facies and no dominant type of cation facies. The GIS-based WQI maps for the study area indicate that the poor quality of water was found the maximum in the pre-monsoon season as compared to the post-monsoon season in the study area, respectively. The high values of WQI in the several groundwater samples of the Bokaro district indicate that water is not suitable for direct consumptions and it required sustainable treatment before its utilization for drinking uses.
\end{abstract}

Keywords Major ion chemistry $\cdot$ Water quality index $\cdot$ Groundwater quality $\cdot$ GIS $\cdot$ Bokaro district

\section{Introduction}

Groundwater is emerging as a critical issue for cities and towns around the world. It is estimated that approximately one-third of the world's population use groundwater for drinking uses (Nickson et al. 2005). In India, the accessibility of surface water is more than groundwater. But, owing to the decentralized availability of groundwater, it is easily

Poornima Verma

poornimaverma2011@gmail.com

1 Department of Environmental Science and Engineering, Indian Institute of Technology (Indian School of Mines), Dhanbad, Jharkhand 826004, India

2 DIATI-Department of Environment, Land and Infrastructure Engineering, Politecnico di Torino, C.so Duca degli Abruzzi 24, 10129 Turin, Italy accessible and forms the largest part of India's agriculture and drinking water supply. Domestic water requirements are fulfilled by groundwater about $50 \%$ of urban water requirement and $85 \%$ of rural domestic requirements (World Bank 1998). However, in recent times, India is fast moving towards a crisis of groundwater overuse and contamination. The rapid increase in population, the growth of industrialization, the use of agricultural chemicals and the disposal of urban and industrial waste have all played a major role in groundwater contamination and increased tremendously the pressure on water resources (Chandra et al. 2015). Once the groundwater is contaminated, its quality cannot be restored by stopping the pollutants from the source, and therefore, it becomes very important to regularly monitor the quality of groundwater and to devise ways and means to protect it (Ramakrishnaiah et al. 2009). Water pollution not only affects water quality, but also threats human health, 
economic development and social prosperity (Milovanovic 2007). Scarcity of clean and potable drinking water has emerged in recent years as one of the most serious developmental issues in many parts of the West Bengal, Jharkhand, Orissa, Western Uttar Pradesh, Andhra Pradesh, Rajasthan and Punjab (Tiwari and Singh 2014). Water quality index (WQI) method is a technique of rating water quality and an effective tool to express water quality that offers a simple, stable, reproducible unit of measure and communicate information on the quality of water to the concerned citizens and policy-makers (Mishra and Patel 2001; Tiwari and Mishra 1985). The water quality index model was originally started by Horton (1965). Brown et al. (1970) developed a water quality index by assigning a proper weight for the parameters based on their analysis. It, thus, becomes an important parameter for the assessment and management of groundwater (Chauhan et al. 2010). In the Jharkhand state, the quality of water is a major issue due to the public ignorance to environmental considerations, lack of provisional basic social services, indiscriminate disposal of increasing anthropogenic and mining wastes and discharges of improperly treated sewage/industrial effluents, resulting in excess accumulation of pollutants on the land surface and contamination of available water resources (Singh and Hasnain 1999; Tiwary 2001; Sarkar et al. 2007). Thus, the main objectives of the present study are to evaluate the spatial and temporal variation in groundwater quality parameters of the Bokaro district to assess its suitability for drinking purposes by using GIS-based WQI model.

\section{Study groundwater sample}

The Bokaro district lies between the latitudes $23^{\circ} 24^{\prime} 27^{\prime \prime}$ $\mathrm{N}$ to $23^{\circ} 57^{\prime} 24^{\prime \prime} \mathrm{N}$ and longitudes $85^{\circ} 34^{\prime} 30^{\prime \prime} \mathrm{E}$ to $86^{\circ} 29^{\prime}$ $10^{\prime \prime} \mathrm{E}$, covering a groundwater sample of $2861 \mathrm{~km}^{2}$ in the state of Jharkhand, India (Fig. 1). It is represented in the Survey of India topographical map no. 73I/73E (1:250,000). The Bokaro district has eight administrative blocks, namely Chas, Gomia, Nawadih, Bermo, Peterwar, Kasmar, Jaridih and Chandankiyari, respectively. The district is experiencing humid with subtropical climate with three distinct seasons that include summer, monsoon and winter. Monsoon sets in the middle of June and last until the end of September. July, August and September are the most humid months of the Bokaro district. The humidity during the winter season is about $60 \%$. Summer stretches from March to June during which the maximum temperature varies from 42 to $46{ }^{\circ} \mathrm{C}$. The average rainfall in the district is $1363.6 \mathrm{~mm} /$ year. The main basin of the groundwater sample is Damodar basin and another sub-basin also occurs like the Ijri, Gobai, Konar, Bokaro, etc. The Damodar River is the main river of the study groundwater sample which flows from West to East direction in the central part of the district. Major tributaries of the Damodar River are the Konar and Jamunia rivers and minor tributaries are the Ijri, Gobai, Tasharkhan, Kadwa, Khanjo rivers, etc. Geomorphology of the study groundwater sample is part of the Chota Nagpur Plateau, which is highly undulating and hilly all over the groundwater sample. The average elevation of the undulating pediplain ranges from 200 to $350 \mathrm{~m}$ above mean sea level. The northern and western part of the study groundwater sample is having hilly ranges where the Gomia is the highest hill prominent block. Hydrogeology of the study groundwater sample, groundwater is mainly replenished by the atmospheric precipitation and its condition is very complicated due to the wide variety of geology, topography, drainage and mining activity. Seepages from canal, streams and other surface water bodies also contribute to the groundwater in the study groundwater sample. Groundwater occurred in the groundwater sample under confined to semiconfined conditions (CGWB 2013). Major parts of the study groundwater sample are underlain by rocks such as granite and granite gneiss. Besides these rocks, quartzites, mica schists and phyllites are also found. The oldest rock of the groundwater sample is unclassified meta-sedimentaries, which comprise quartzite and quartz schists. Three-fourths of the groundwater sample is occupied by rocks of Chota Nagpur granite gneiss. Coal, shale and sandstone deposits are found in parts of Bermo and Gomia blocks of the Bokaro district (Satapathy and Syed 2015).

\section{Materials and methods}

For the assessment of the groundwater quality of the Bokaro district, one hundred two groundwater samples (fifty-one in the pre-monsoon season and fifty-one in the post-monsoon season) were collected from bore hole and dug well during the month of December 2014 and May 2015 (Fig. 1). Care was taken to collect subsequent samples from the same location in both seasons. In the laboratory, the water samples were filtered through $0.45-\mu \mathrm{m}$ Millipore membrane filters to separate suspended particles. The $\mathrm{pH}$ and $\mathrm{EC}$ of water samples were measured in the field immediately after the collection of the samples by using Multiparameter probe (PCSTestr 35). Major cations $\left(\mathrm{Ca}^{2+}, \mathrm{Na}^{+}\right.$, and $\left.\mathrm{K}^{+}\right)$were analysed by using Systronics Flame Photometer 128. Magnesium, TH, bicarbonate and chloride were estimated by a titrimetric method using standard EDTA, $\mathrm{HCl}$ and $\mathrm{AgNO}_{3}$ as titration solution (APHA 2012). Sulphate, fluoride and nitrate were estimated by using the UV-Vis spectrophotometer. Calculated ionic balance error was found within the permissible limit of $\pm 10 \%$, and the ratio of TDS/EC is within acceptable limits $(0.8)$ for confirming the reliability of the analytical results. 


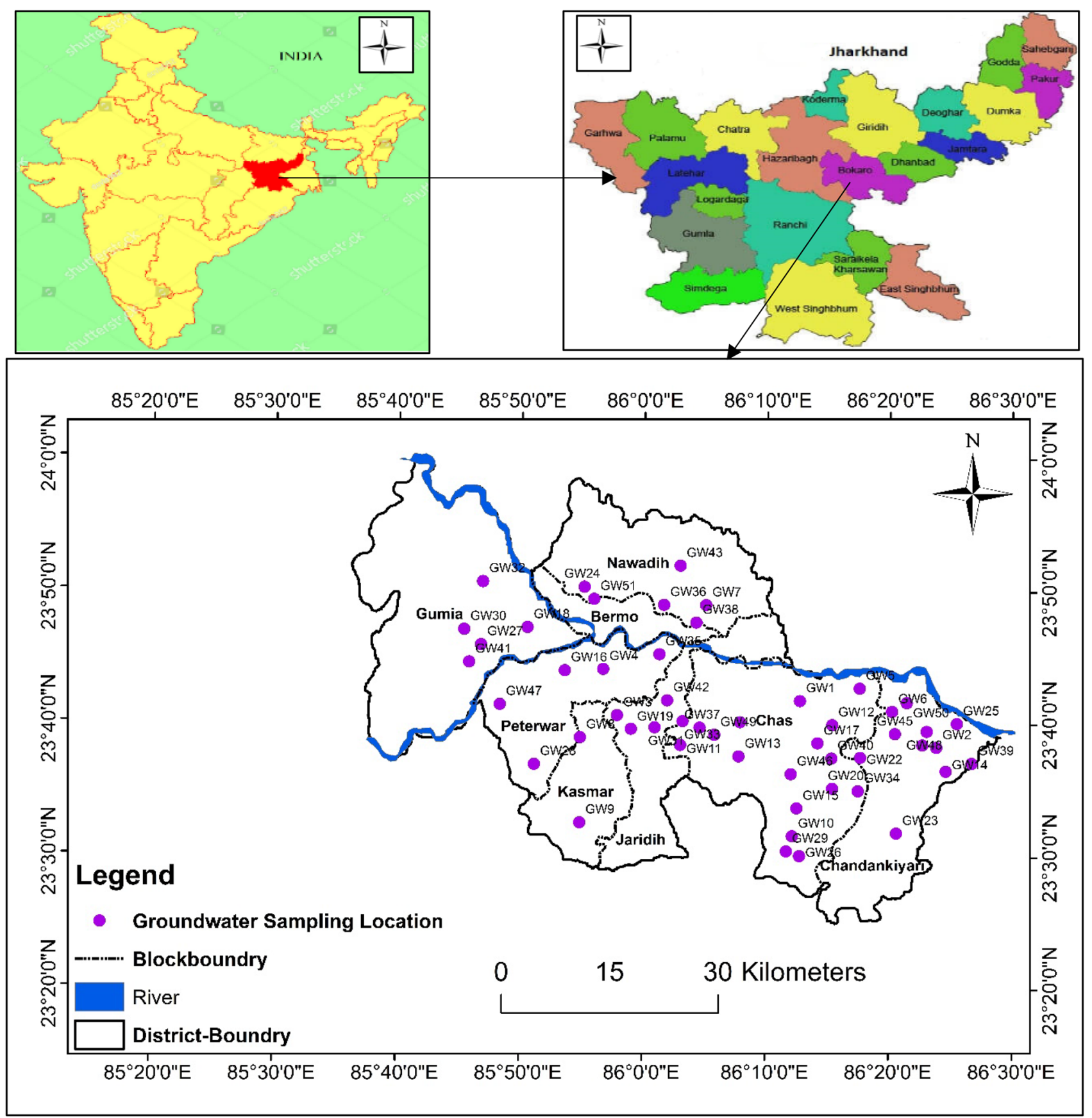

Fig. 1 Groundwater sample location in the Bokaro district

\section{Water quality index computing}

Water quality index (WQI) was used for evaluating the composite influence of individual water quality parameter on the overall quality of water (Mitra et al. 2006; Yadav et al. 2015). WQI is a mathematical equation used to summarize a large number of water quality data into a single number and understandable format (Štambuk-Giljanovic 1999). In assessing the suitability of drinking water, the water quality data of the analysed samples were compared with the recommended drinking water standard of BIS (2012) which have been considered for the calculation of WQI are given in Table 1. In computing WQI, three steps are followed. In the first step, each of the 13 parameters $\left(\mathrm{pH}, \mathrm{TDS}, \mathrm{F}^{-}, \mathrm{Cl}^{-}, \mathrm{NO}_{3}{ }^{-}, \mathrm{SO}_{4}{ }^{2-}\right.$, $\left.\mathrm{HCO}_{3}{ }^{-}, \mathrm{Ca}^{2+}, \mathrm{Mg}^{2+}, \mathrm{Na}^{+}, \mathrm{K}^{+}, \mathrm{TH}\right)$ has been allotted a weight $\left(w_{i}\right)$ according to its relative importance in the overall quality of water for drinking purposes are listed in Table 1 . The maximum weight of 5 has been allotted to the parameters like 
Table 1 Relative weight of chemical parameters

\begin{tabular}{llll}
\hline Parameters & Weight $\left(w_{i}\right)$ & $\begin{array}{l}\text { Relative } \\
\text { weight } \\
\left(W_{i}=k / S_{i}\right)\end{array}$ & $\begin{array}{l}\text { BIS } \\
\text { (IS:10500) } \\
(2012)\end{array}$ \\
\hline $\mathrm{pH}$ & 4 & 0.108 & $6.5-8.5$ \\
$\mathrm{TDS}(\mathrm{mg} / \mathrm{L})$ & 5 & 0.135 & 500 \\
Total hardness $(\mathrm{mg} / \mathrm{L})$ & 2 & 0.054 & 200 \\
$\mathrm{~F}^{-}(\mathrm{mg} / \mathrm{L})$ & 5 & 0.135 & 1.0 \\
$\mathrm{Cl}^{-}(\mathrm{mg} / \mathrm{L})$ & 5 & 0.135 & 250 \\
$\mathrm{NO}_{3}{ }^{-}(\mathrm{mg} / \mathrm{L})$ & 5 & 0.108 & 45 \\
$\mathrm{SO}_{4}{ }^{-}(\mathrm{mg} / \mathrm{L})$ & 4 & 0.108 & 200 \\
$\mathrm{HCO}_{3}^{-}(\mathrm{mg} / \mathrm{L})$ & 1 & 0.081 & 200 \\
$\mathrm{Ca}^{2+}(\mathrm{mg} / \mathrm{L})$ & 3 & 0.081 & 75 \\
$\mathrm{Mg}^{2+}(\mathrm{mg} / \mathrm{L})$ & 3 & 0.081 & 30 \\
& $w_{i}=37$ & $W_{i}=1.0$ & \\
\hline
\end{tabular}

TDS, $\mathrm{F}^{-}, \mathrm{Cl}^{-}$and $\mathrm{NO}_{3}{ }^{-}$owing to main significance in water quality assessment (Vasanthavigar et al. 2010; Tiwari et al. 2017). $\mathrm{HCO}_{3}{ }^{-}$and $\mathrm{TH}$ are given the minimum weight of 1 and 2 assigned. Other parameters like $\mathrm{Ca}^{2+}, \mathrm{Mg}^{2+}, \mathrm{Na}^{+}$and $\mathrm{HCO}_{3}{ }^{-}$were assigned a weight $\left(W_{i}\right)$ between 3 and 4 depending on their importance in water quality determination. In the second step, the relative weight $\left(W_{i}\right)$ is computed from the following equation as it plays an insignificant role in the water quality assessment.

$W_{i}=\frac{W_{i}}{\sum_{i=1}^{n} W_{i}}$

where the $W_{i}$ is the relative weight, $W_{i}$ is the weight of each parameter and $n$ is the number of parameters. Calculated relative weight $W_{i}$ values of each parameter are given in Table 1.

In the third step, a quality rating scale $\left(q_{i}\right)$ for each parameter was computed by dividing its concentration in each water sample by its respective standard concentration prescribed by the guidelines of BIS (2012) and the result is multiplied by 100:

$q_{i}=\left(\frac{C_{i}}{S_{i}}\right) \times 100$

where the $q_{i}$ is the quality rating scale, $C_{i}$ is the concentration of each chemical parameters in each water sample in $\mathrm{mg} / \mathrm{L}$ and $S_{i}$ is the BIS for each chemical parameter in $\mathrm{mg} / \mathrm{L}$ according to the guidelines of the BIS (2012).

$\mathrm{SI}_{i}=w_{i} \times q_{i}$

$\mathrm{WQI}=\sum_{i=1}^{n} \mathrm{SI}_{i}$
Table 2 Classification of WQI range and category of water

\begin{tabular}{ll}
\hline WQI & Status \\
\hline$<50$ & Excellent water \\
$50-100$ & Good water \\
$100-200$ & Poor water \\
$200-300$ & Very poor water \\
$>300$ & Unfit for drinking purpose \\
\hline
\end{tabular}

For computing the WQI, the $\mathrm{SI}_{i}$ is first determined for each chemical parameter, which is then used to determine the WQI as per the following equation, where the $\mathrm{SI}_{i}$ is the sub-index of $i$ th parameter, $q_{i}$ is the rating based on concentration of $i$ th parameter and $n$ is the number of parameters.

Calculated water quality index was classified into five groups excellent water to water unsuitable for drinking purpose of range water quality index for drinking purpose and is given in Table 2 .

\section{Spatial analysis}

The spatial analysis of various physicochemical parameters was carried out by using GIS contouring methods with ArcGIS 10.3. The inverse distance weighted (IDW) interpolation techniques have been used for preparing the spatial distribution maps for each physicochemical parameter. The spatial distribution map of the $\mathrm{pH}, \mathrm{EC}$, TDS, TH, cations $\left(\mathrm{Ca}^{2+}, \mathrm{Mg}^{2+}, \mathrm{Na}^{+}\right.$and $\left.\mathrm{K}^{+}\right)$and anions $\left(\mathrm{Cl}^{-}, \mathrm{SO}_{4}{ }^{2-}, \mathrm{HCO}_{3}{ }^{-}\right.$, $\mathrm{F}^{-}$, and $\mathrm{NO}_{3}^{-}$) have been generated for Bokaro district. The methodology in Fig. 2 was involved in the mapping of physicochemical parameters and development of drinking water quality index map for the pre-and post-monsoon seasons based on the BIS (2012) for drinking water.

\section{Results and discussion}

The analysed parameters of the groundwater samples were compared with drinking water quality standards established by the WHO (2004) and BIS (2012) for drinking and public health purpose (Table 3). Moreover, the statistical analysis of the groundwater samples and consequences of the elements beyond the drinking water limit are presented in Table 3.

\section{Drinking water quality mapping}

Spatial analysis of $\mathrm{pH}$, TDS, TH, $\mathrm{Ca}^{2+}, \mathrm{Mg}^{2+}, \mathrm{Na}^{+}, \mathrm{K}^{+}, \mathrm{Cl}^{-}$, $\mathrm{SO}_{4}{ }^{2-}, \mathrm{HCO}_{3}{ }^{-}, \mathrm{F}^{-}$and $\mathrm{NO}_{3}{ }^{-}$parameters in the groundwater samples of the Bokaro district during the pre- and postmonsoon seasons is shown in Figs. 3, 4 and 5. $\mathrm{pH}$ of the analysed water samples varied from 5.67 to 8.09 in the premonsoon season and from 6.88 to 7.92 in the post-monsoon 
Fig. 2 Flowchart for the method adopted (Chatterjee et al. 2010)

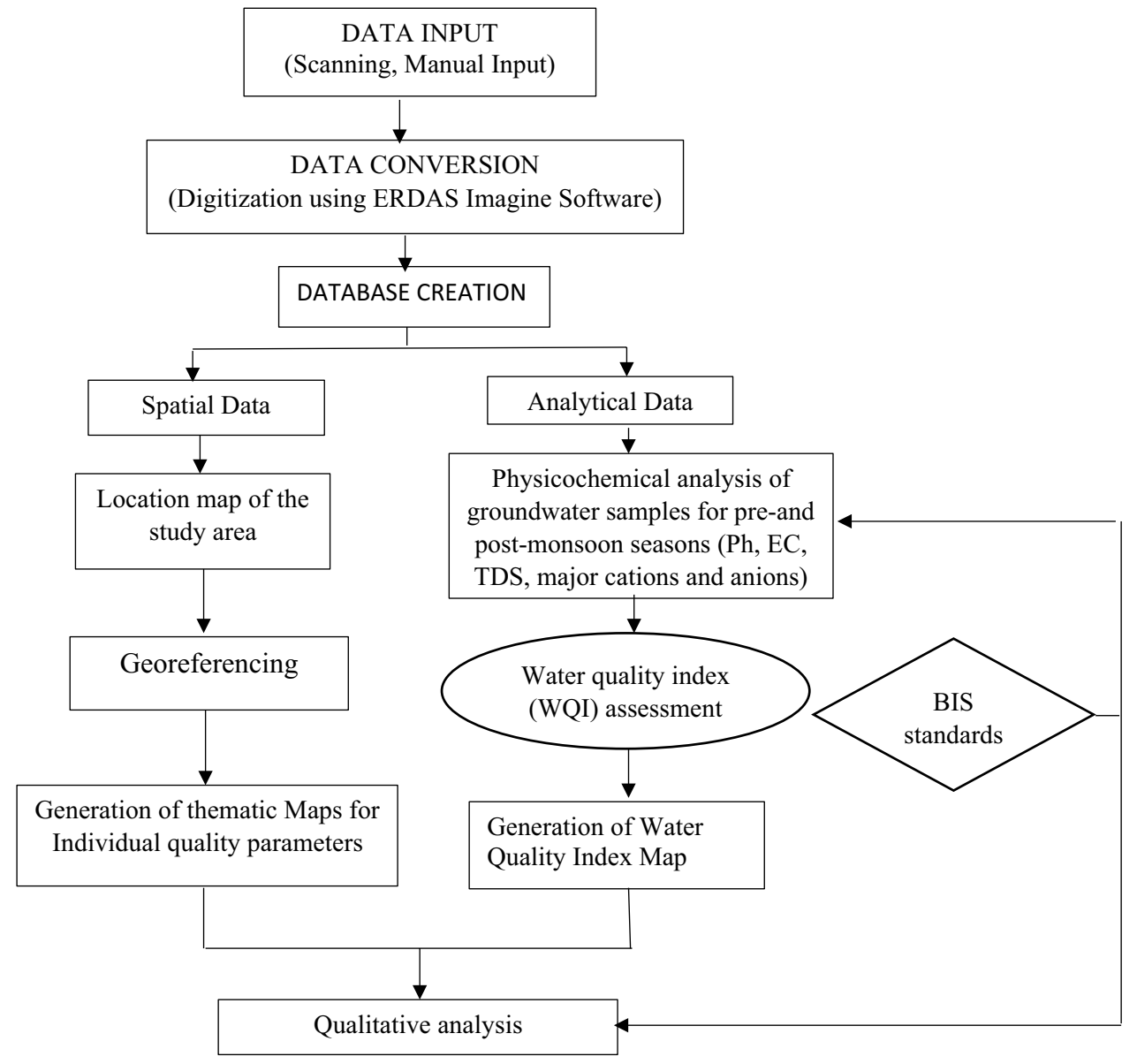

season, indicating slightly acidic to alkaline nature of the groundwater samples, respectively. Spatial analysis of $\mathrm{pH}$ value of the groundwater samples (Fig. 3a) indicates all of the water samples were within the permissible limits (6.5-8.5) of the BIS (2012) except at one site in the western side of the study area during the pre-monsoon season. The electrical conductivity (EC) value of the groundwater samples ranged from 520.00 to $1961.00 \mu \mathrm{s} / \mathrm{cm}$ (avg. $1142.22 \mu \mathrm{s} /$ $\mathrm{cm}$ ) during the pre-monsoon season and from 304.00 to $1620.00 \mu \mathrm{s} / \mathrm{cm}$ (avg. $860.80 \mu \mathrm{s} / \mathrm{cm}$ ) in the post-monsoon season, respectively. Spatial analysis of EC (Fig. 3b) of the groundwater shows that the major part of the study area had higher EC values ( $>1000 \mu \mathrm{s} / \mathrm{cm}$ ) during both seasons. The concentration of TDS in the groundwater of the study area ranged from 414.00 to $1735.00 \mathrm{mg} / \mathrm{L} \mathrm{(avg.} 961.69 \mathrm{mg} / \mathrm{L}$ ) in the pre-monsoon and from 258.00 to $1454.00 \mathrm{mg} / \mathrm{L}$ (avg. $702.96 \mathrm{mg} / \mathrm{L}$ ) in the post-monsoon season. Spatial analysis of TDS concentrations of the groundwater (Fig. 3c) shows that $11.76,76.48$ and $11.76 \%$ of the groundwater sample falls within the acceptable $(<500 \mathrm{mg} / \mathrm{L})$, permissible (500-1500 mg/L) and above the permissible (>1500 mg/L) limit, respectively, during the pre-monsoon period as per the WHO (2004) standard, while 31.37 and $68.63 \%$ of the groundwater sample falls within the acceptable and permissible limit during the post-monsoon season. The high concentrations of TDS beyond the acceptable and permissible limit were observed during the pre-monsoon period in the eastern side and some portion of the western side of the study area (Fig. 3c). Moreover, during the post-monsoon season, the TDS values were within the maximum permissible limit as per the WHO (2004) and BIS (2012) drinking water standards (Fig. 3c). We found the level of TDS concentrations was less high in the post-monsoon season as compared to the pre-monsoon season, and this may be due to the dilution with rainwater (Jasmin and Mallikarjuna, 2014). Total hardness in the groundwater samples ranged from 172.62 to $973.73 \mathrm{mg} / \mathrm{L}$ and 121.30 to $817.77 \mathrm{mg} / \mathrm{L}$ with the average value of 488.49 and $371.07 \mathrm{mg} / \mathrm{L}$ during the pre-and post-monsoon season, respectively. The spatial distribution map of TH (Fig. 3d) shows that 3.92, 64.73 and $31.35 \%$ of the groundwater sample falls within the acceptable $(<200 \mathrm{mg} / \mathrm{L})$, permissible $(200-600 \mathrm{mg} / \mathrm{L})$ and above the permissible ( $>600 \mathrm{mg} / \mathrm{L}$ ) limit, respectively, recommended by the BIS (2012) during the pre-monsoon season, while during the post-monsoon season, 19.60, 68.64 and $11.76 \%$ of the samples were within the acceptable, permissible and above the permissible limit. The high concentrations of TH beyond permissible limit were observed during 


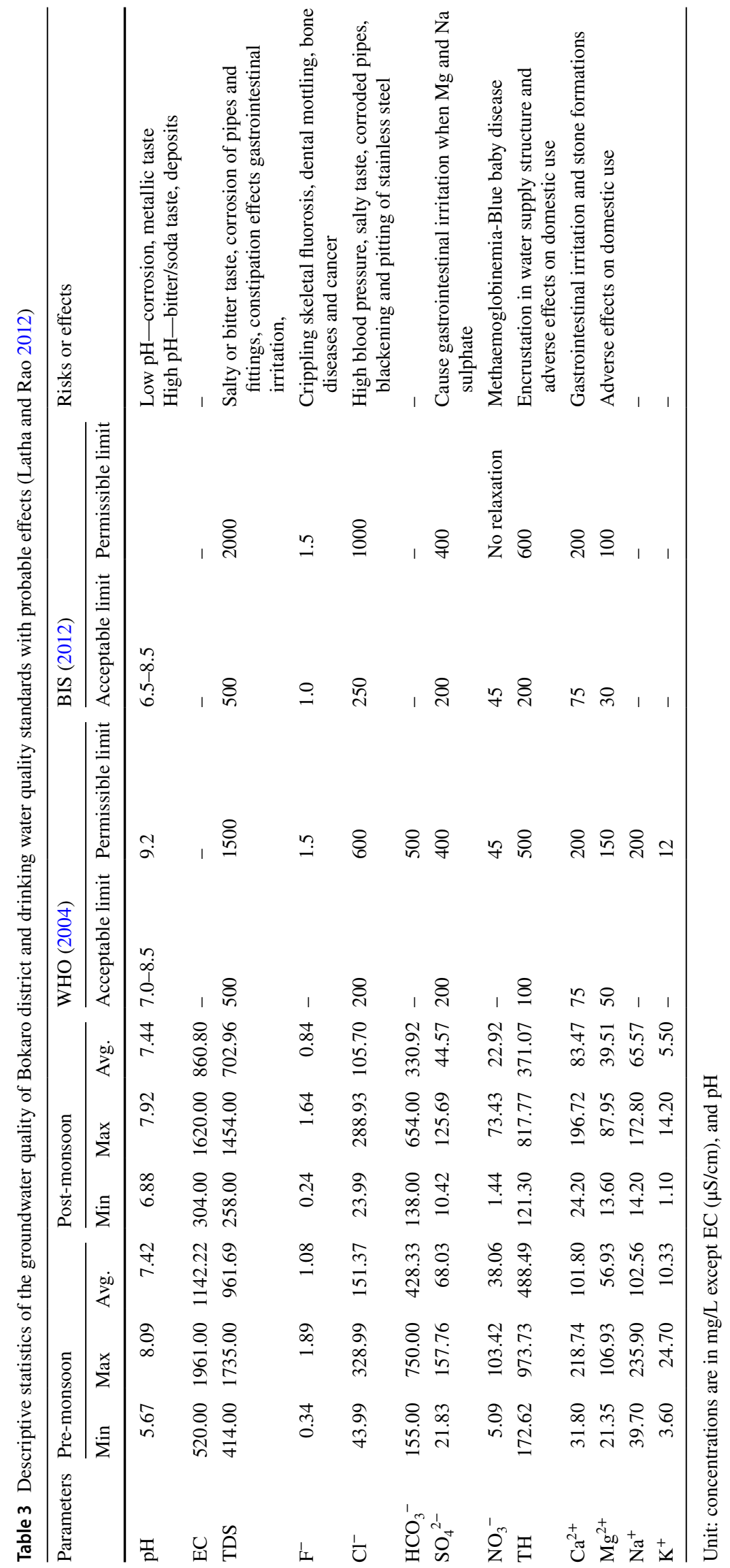


(a)

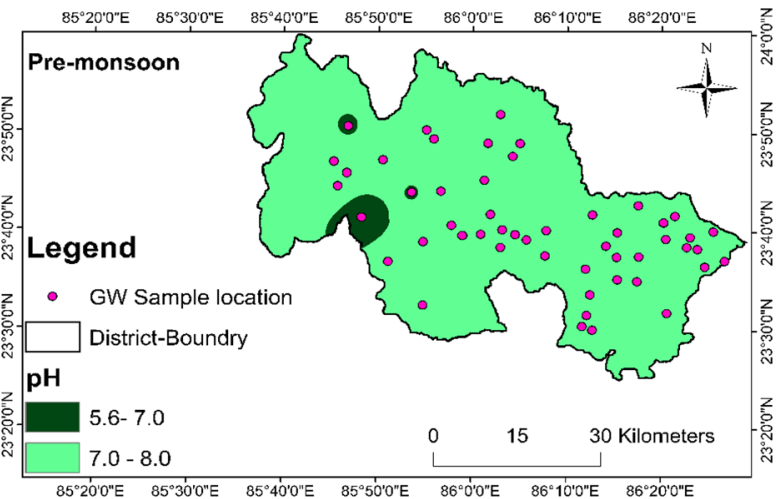

(b)

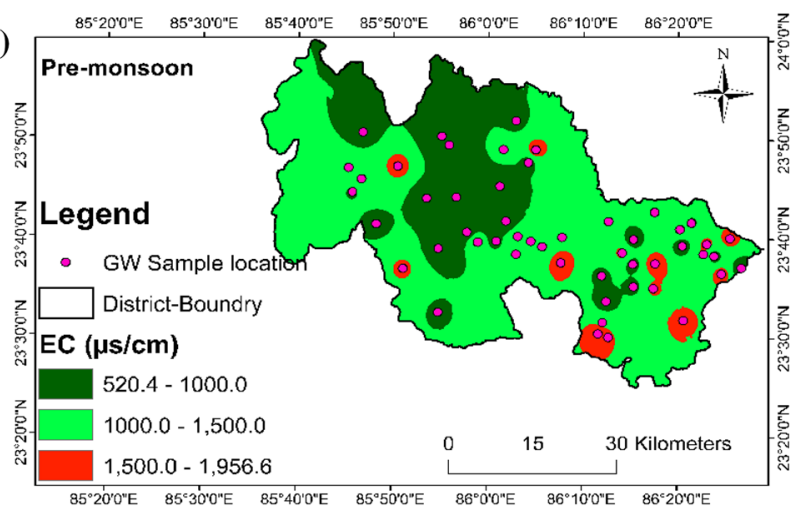

(c)

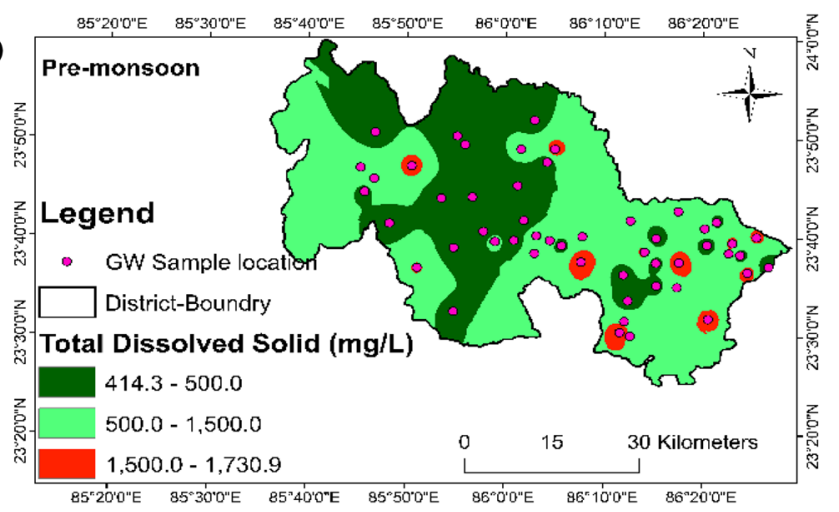

(d)

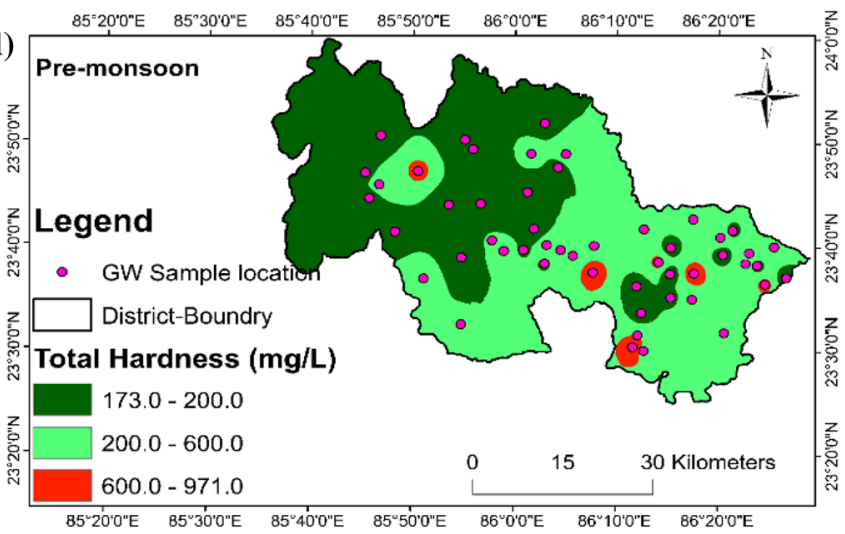

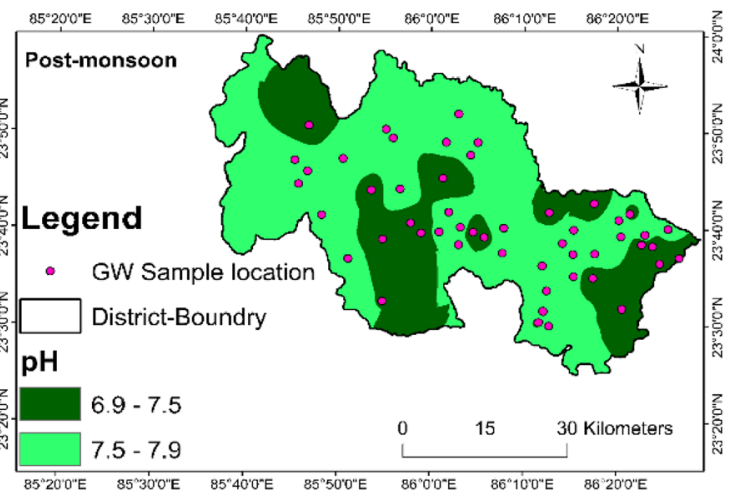
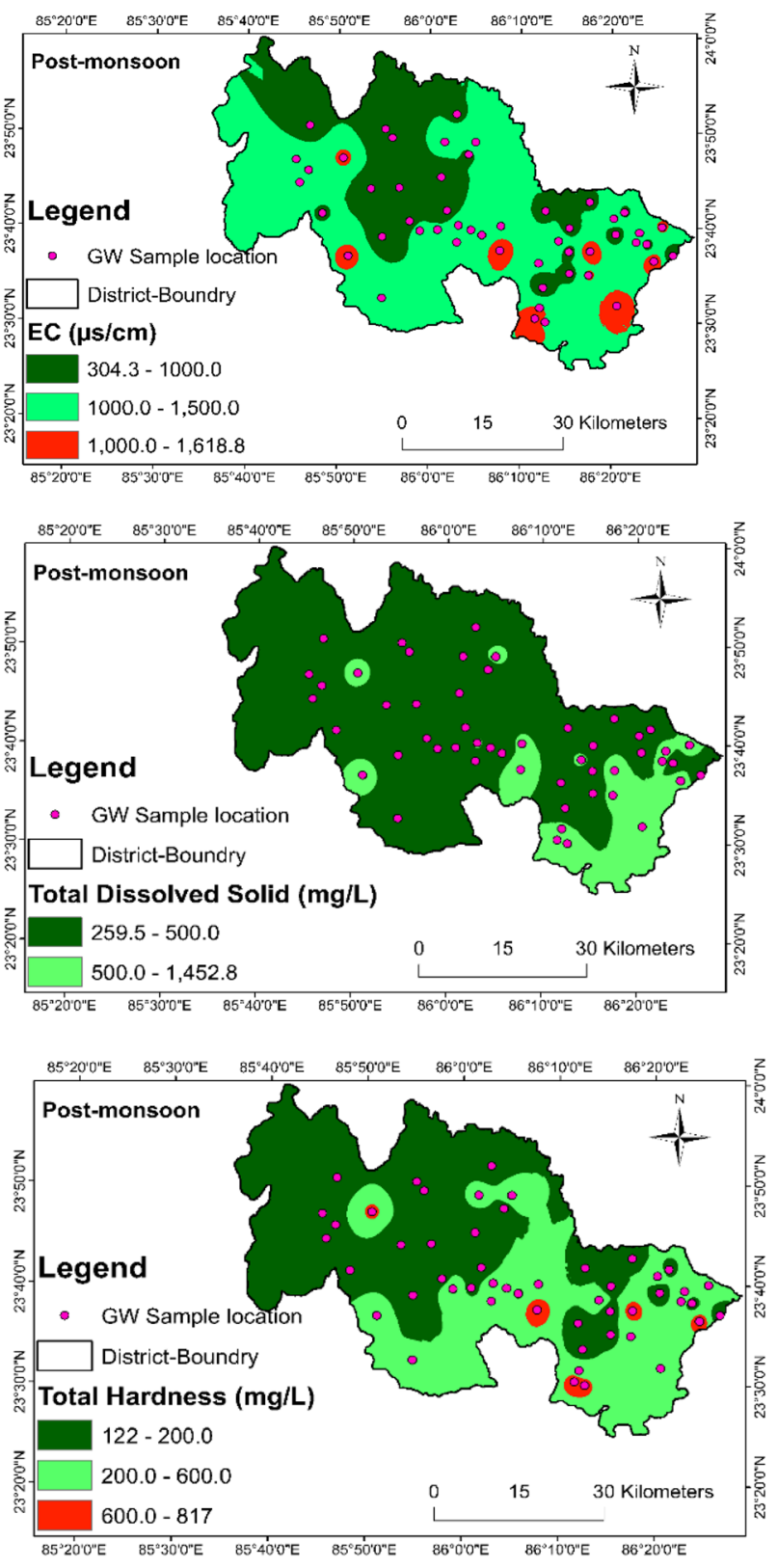

Fig. 3 Spatial variations in $\mathrm{pH}, \mathrm{EC}, \mathrm{TDS}$ and $\mathrm{TH}$ 

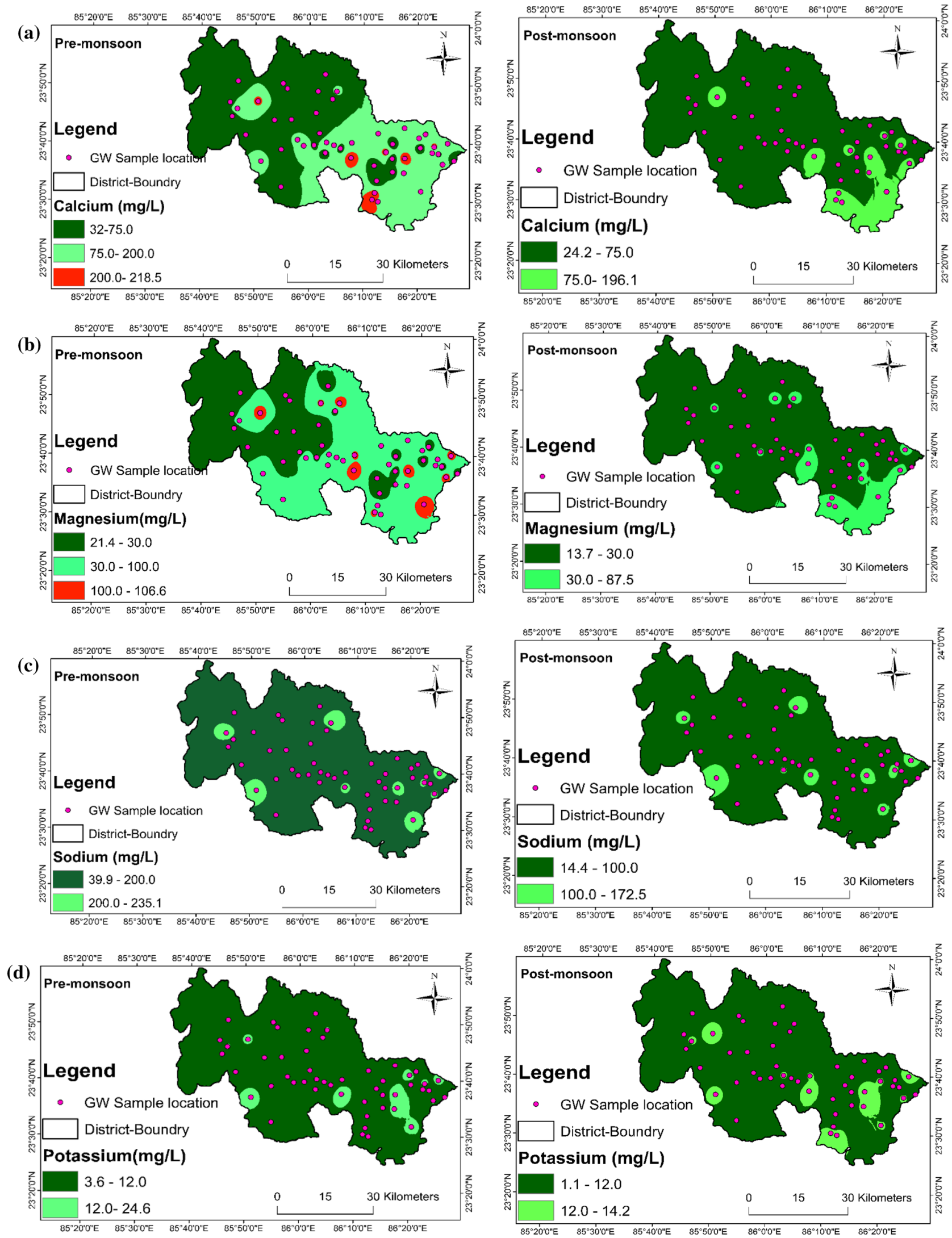

Fig. 4 Spatial variation in cations 


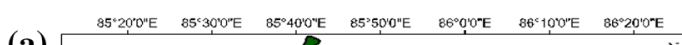

(a) Pre-monsoon

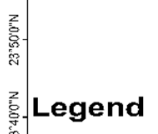

- Gw Sample location

$\square$ District-Boundry

Bicarbonate (mg/L)

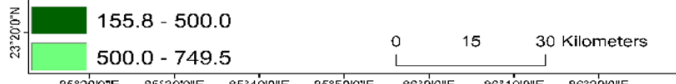

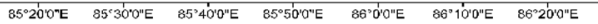

(b)

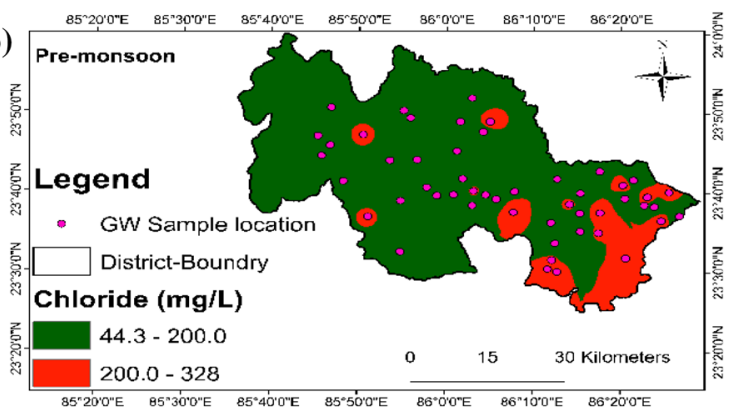

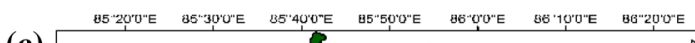

(c) Pre-monsoon

旁.

\section{Legend}

- GW Sample location District-Boundry

Nitrate(mg/L)

$5.1-45.0$

45.0-103.1

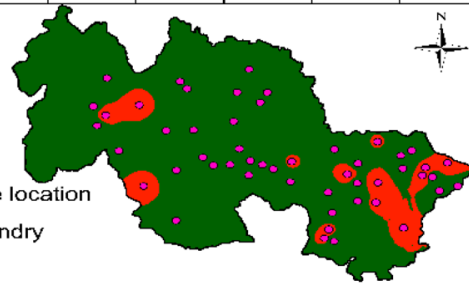

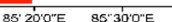

(d)

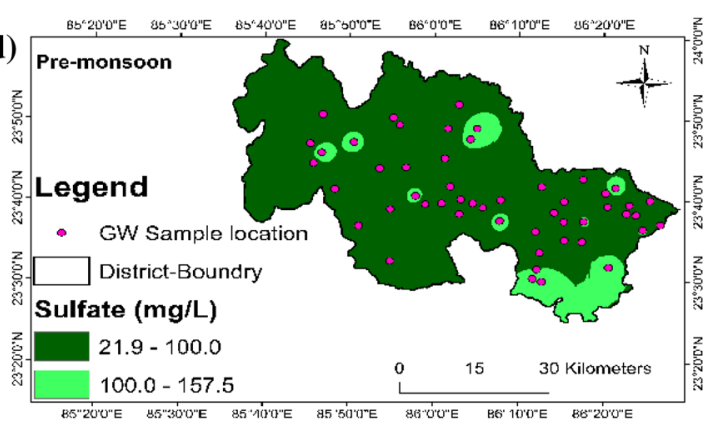

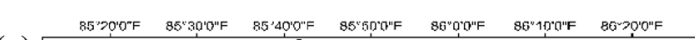

(e) Pre-monsoon

宷.

Legend

District-Boundry

Fluoride(mg/L)

\begin{tabular}{l|l} 
& $0.3-1.0$ \\
$\square$ & $1.0-1.5$ \\
& $1.5-1.9$
\end{tabular}

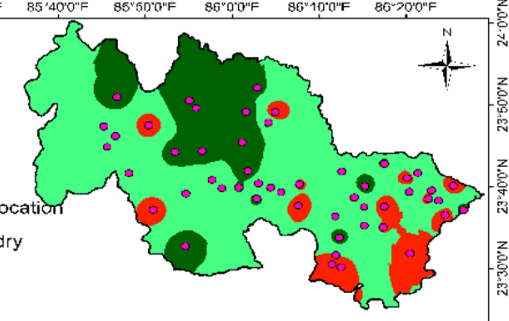

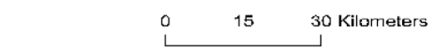

8. 20'0"E
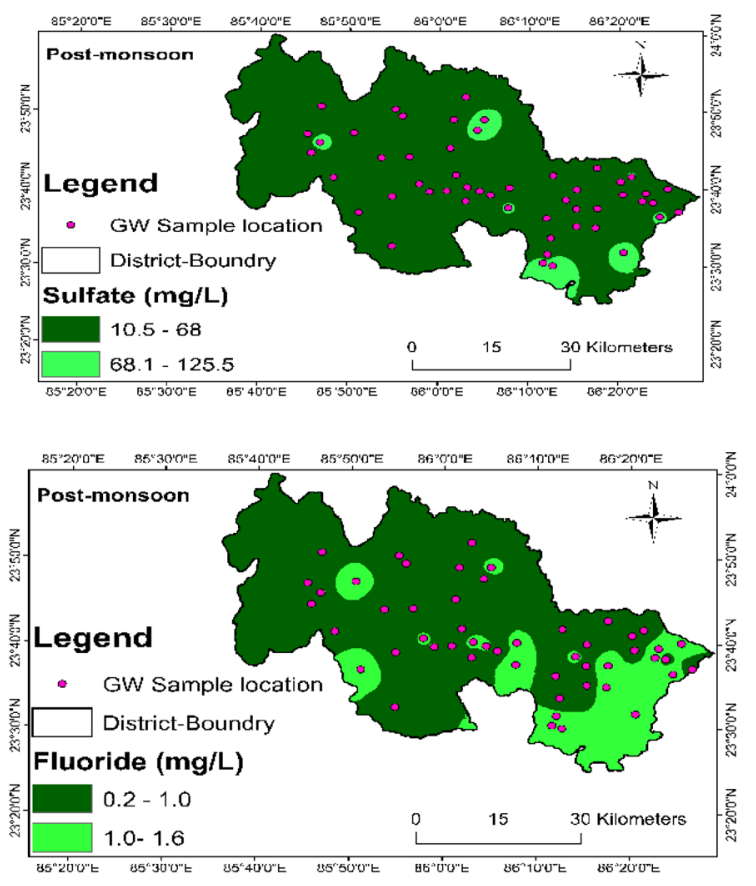

Fig. 5 Spatial variation in anions
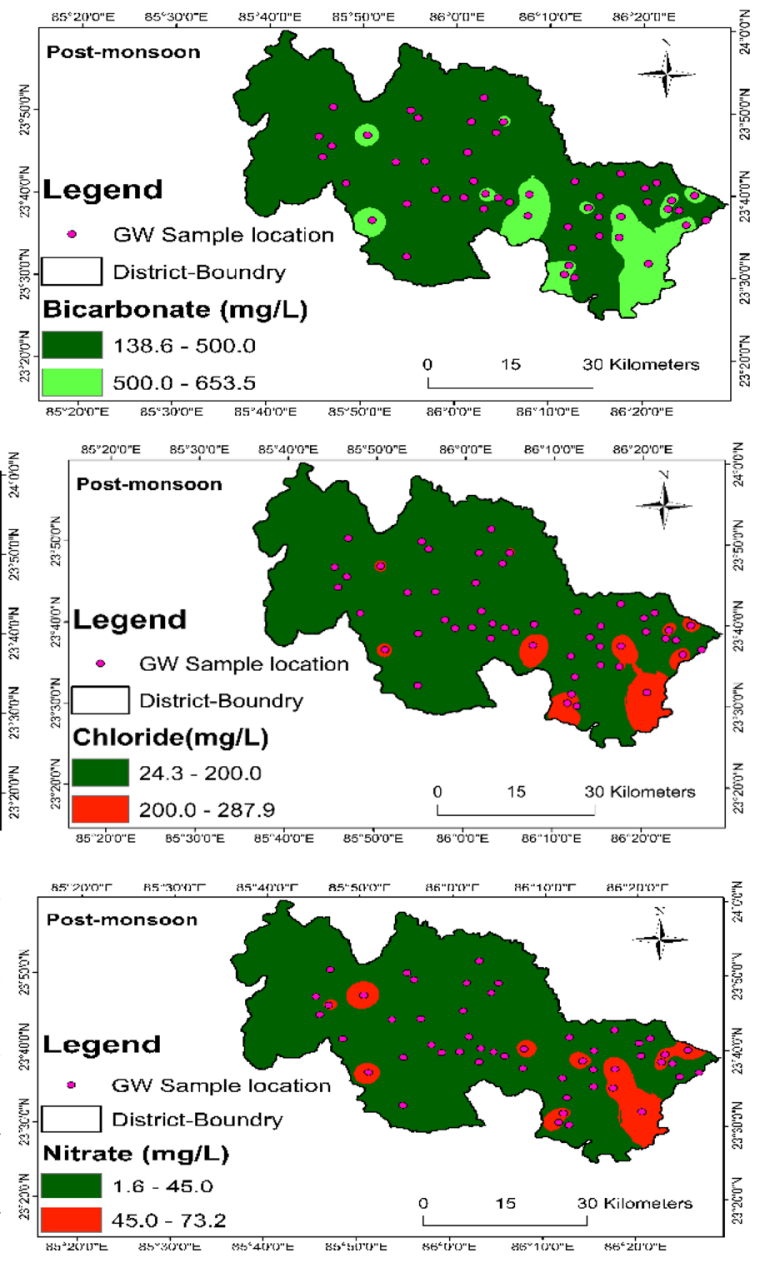
both seasons in the study area (Fig. 3d). $\mathrm{Ca}^{2+}$ in the groundwater samples of the study area varied from 31.80 to $218.74 \mathrm{mg} / \mathrm{L}$ with an average value of $101.80 \mathrm{mg} / \mathrm{L}$ in the pre-monsoon season and from 24.20 to $196.72 \mathrm{mg} / \mathrm{L}$ with an average value of $83.47 \mathrm{mg} / \mathrm{L}$ in the post-monsoon season, respectively. The spatial analysis of $\mathrm{Ca}^{2+}$ (Fig. 4a) shows that the groundwater samples fall within the acceptable $(<75 \mathrm{mg} / \mathrm{L})$, permissible $(75-200 \mathrm{mg} / \mathrm{L})$ and above permissible (>200 mg/L) limits affect to 39.21, 54.91 and 5.88\%, respectively, during the pre-monsoon season, recommended by the BIS (2012) and WHO (2004) standards, while 47.06 and $52.94 \%$ of the groundwater sample falls within the acceptable and permissible limit during the post-monsoon season in the study area. However, none of the groundwater samples falls above permissible limit during the post-monsoon, may be due to the influence of monsoon. Concentration of $\mathrm{Mg}^{2+}$ in the study area ranged from 21.35 to $106.93 \mathrm{mg} / \mathrm{L}$ (avg. $56.93 \mathrm{mg} / \mathrm{L}$ ) and 13.60 to $87.95 \mathrm{mg} / \mathrm{L}$ (avg. $39.51 \mathrm{mg} / \mathrm{L}$ ) in the pre- and post-monsoon seasons, respectively. The spatial analysis of $\mathrm{Mg}^{2+}$ (Fig. 4b) shows that $15.1,81.1$ and $3.8 \%$ of the groundwater sample, respectively, falls within the acceptable $(<30 \mathrm{mg} / \mathrm{L})$, permissible $(30-100 \mathrm{mg} / \mathrm{L})$ and above permissible $(>100 \mathrm{mg} / \mathrm{L})$ limit during the pre-monsoon season, recommended by the BIS (2012), while 41.17 and $58.83 \%$ of the groundwater sample falls within the acceptable and permissible limit during the post-monsoon season. Concentrations of $\mathrm{Na}^{+}$ranged from 39.70 to $235.90 \mathrm{mg} / \mathrm{L}$ (avg. $102.56 \mathrm{mg} / \mathrm{L}$ ) and from 14.20 to $172.80 \mathrm{mg} / \mathrm{L}$ (avg. $65.57 \mathrm{mg} / \mathrm{L}$ ), in the pre-and post-monsoon seasons, respectively. The spatial analysis of $\mathrm{Na}^{+}$ (Fig. 4c) reveals that $96.1 \%$ of the groundwater sample falls within permissible limit, and only $3.9 \%$ of the groundwater sample falls above permissible limit (>200 mg/L) during the pre-monsoon period recommended by the WHO (2004) standard, while the total groundwater sample of the Bokaro district falls within the permissible limit $(<200 \mathrm{mg} / \mathrm{L})$ during the post-monsoon season. Concentration of $\mathrm{K}^{+}$varied from 3.60 to $24.70 \mathrm{mg} / \mathrm{L}$ (avg. $10.33 \mathrm{mg} / \mathrm{L}$ ) in the pre-monsoon season and from 1.10 to $14.20 \mathrm{mg} / \mathrm{L}$ (avg. $5.50 \mathrm{mg} / \mathrm{L}$ ) in the post-monsoon season, respectively. The spatial analysis of $\mathrm{K}^{+}$(Fig. $4 \mathrm{~d}$ ) indicates that $70.58 \%$ of the groundwater sample falls within permissible limit $(<12 \mathrm{mg} / \mathrm{L})$ and $23.52 \%$ of the groundwater sample exceeding permissible limit ( $>12 \mathrm{mg} / \mathrm{L})$ during the pre-monsoon season, while $96.07 \%$ of the groundwater sample falls within permissible limit, and only $3.9 \%$ of the groundwater sample falls above permissible limit during the post-monsoon season as per the WHO (2004) standard. Evaporate encrustations of $\mathrm{Na}^{+}$and $\mathrm{K}^{+}$salts, which develop due to cyclic wetting and drying of the Damodar River and cause the formation of alkaline/ saline soils, also serve as a local source of $\mathrm{Na}^{+}$and $\mathrm{K}^{+}$ (Singh et al. 2005; Tiwari et al. 2016). $\mathrm{HCO}_{3}{ }^{-}$is the dominant anion among the other anions, varied from 155.00 to
$750.00 \mathrm{mg} / \mathrm{L}$ (avg. $428.33 \mathrm{mg} / \mathrm{L}$ ) and from 138.00 to $654.00 \mathrm{mg} / \mathrm{L}$ (avg. $330.92 \mathrm{mg} / \mathrm{L}$ ), in the pre- and post-monsoon seasons, respectively. The spatial analysis of $\mathrm{HCO}_{3}{ }^{-}$(Fig. 5a) indicates that $64.71 \%$ of the groundwater sample falls within permissible limit $(<500 \mathrm{mg} / \mathrm{L})$, and $35.29 \%$ of groundwater sample beyond the permissible limit (>500 mg/L), during the pre-monsoon season, while $92.8 \%$ of the groundwater sample falls within permissible limit, and $7.20 \%$ of the groundwater sample beyond permissible limit during the post-monsoon season, recommended by the WHO (2004) standards. In groundwater samples, higher concentration of $\mathrm{HCO}_{3}{ }^{-}$is due to the carbonate weathering as well as dissolution of carbonic acid in the aquifers and decay of organic matter in the soil zone (Canter 1997; Jeong 2001; Zilberbrand et al. 2001). Weathering of silicate minerals and $\mathrm{Na}^{+}, \mathrm{K}^{+}$feldspar additionally also increases the concentration of $\mathrm{HCO}_{3}{ }^{-}$in the groundwater samples. Concentration of $\mathrm{Cl}^{-}$in the pre- and post-monsoon seasons varied from 43.99 to $328.99 \mathrm{mg} / \mathrm{L}$ (avg. $151.37 \mathrm{mg} / \mathrm{L}$ ) and 23.99 to $288.93 \mathrm{mg} / \mathrm{L}$ (avg. $105.70 \mathrm{mg} / \mathrm{L}$ ), respectively. The spatial analysis of $\mathrm{Cl}^{-}$(Fig. 5b) shows that $72.54 \%$ of the district groundwater sample falls within the acceptable limit $(<200 \mathrm{mg} / \mathrm{L})$ and $27.45 \%$ within the permissible limit ( $>200 \mathrm{mg} / \mathrm{L}$ ) during the pre-monsoon season, while 92.15 and $7.84 \%$ of the district groundwater sample falls within the acceptable and permissible limit during the post-monsoon season. Nitrate concentration varied from 5.09 to $103.42 \mathrm{mg} / \mathrm{L}$ (avg. $38.06 \mathrm{mg} / \mathrm{L}$ ) in the pre-monsoon season and from 1.44 to $73.43 \mathrm{mg} / \mathrm{L}$ (avg. $22.92 \mathrm{mg} / \mathrm{L}$ ) in the postmonsoon season. The spatial analysis of $\mathrm{NO}_{3}{ }^{-}$(Fig. 3c) displays that $60.78 \%$ of the district groundwater sample falls within the acceptable limit $(<45 \mathrm{mg} / \mathrm{L})$ and $39.21 \%$ within the permissible limit ( $>45 \mathrm{mg} / \mathrm{L}$ ) during the pre-monsoon season, while 74.50 and $25.49 \%$ of the district groundwater sample falls within the acceptable and permissible limit recommended by BIS (2012) and WHO (2004) standard during the post-monsoon season. The chief sources of chloride and nitrate are atmospheric precipitation, application of fertilizers, animals waste and discharges of municipal or domestic sewage (Appelo and Postma 1996; Singh et al. 2013; Tiwari et al. 2016). Sulphate concentrations ranged from 21.83 to $157.76 \mathrm{mg} / \mathrm{L}$ (avg. $68.03 \mathrm{mg} / \mathrm{L}$ ) in the pre-monsoon season and from 10.42 to $125.69 \mathrm{mg} / \mathrm{L}$ (avg. $44.57 \mathrm{mg} / \mathrm{L}$ ) in the post-monsoon season. The spatial analysis of sulphate (Fig. 5d) shows that entire groundwater sample falls within the acceptable limit $(<200 \mathrm{mg} / \mathrm{L})$ recommended by the BIS (2012) and WHO (2004) standard during the pre- and postmonsoon season. Fluoride concentrations varied from 0.34 to 1.89 and 0.24 to $1.64 \mathrm{mg} / \mathrm{L}$ with an average value of 1.08 and $0.84 \mathrm{mg} / \mathrm{L}$ in the pre- and post-monsoon season, respectively. The spatial analysis of $\mathrm{F}^{-}$(Fig. 5e) in the groundwater sample indicates that $56.90,19.58$ and $23.52 \%$ of the groundwater sample, respectively, falls within the acceptable 
$(<1.0 \mathrm{mg} / \mathrm{L})$ permissible $(1.0-1.5 \mathrm{mg} / \mathrm{L})$ and exceeding permissible limit ( $>1.5 \mathrm{mg} / \mathrm{L}$ ) during the pre-monsoon season, while $64.70,26.20,9.1 \%$ of the groundwater sample, respectively, falls within the acceptable, permissible and exceeding permissible limit during the post-monsoon season. It is an essential element for maintaining normal development of teeth and bones. Fluoride in groundwater may be derived from the weathering of fluoride-bearing minerals like muscovite, biotite, fluorite and fluoroapatite occurred as accessories minerals in the granites and granitic gneisses, besides industrial and agricultural sources (Appelo and Postma 1996; Singh et al. 2011).

\section{Ternary diagrams and Durov diagram}

Ternary diagrams for anions and cations are plotted for the pre- and post-monsoon seasons, respectively (Fig. 6a, b). Most of the groundwater samples shows no dominant type in the cation ternary diagram, while the $\mathrm{HCO}_{3}^{-}$type in the anion ternary diagram during the both seasons, respectively. However, the cation ternary diagram shows that few groundwater samples are dominated by sodium and calcium during both seasons, respectively. Consequently, two types of prominent hydrochemical facies are observed in the study groundwater sample. $\mathrm{Ca}-\mathrm{HCO}_{3}$ and $\mathrm{Na}-\mathrm{HCO}_{3}$ types of the groundwater were found during both seasons, respectively. The hydrochemical facies does not affect much due to the effluence of monsoon season in the study area.

The major cation and anion concentrations of the samples collected from the groundwaters in the study area were plotted on the Durov diagram (Fig. 7). Durov diagram (1948) helps the interpretation of the evolutionary trends and provides more information on the hydrochemical processes

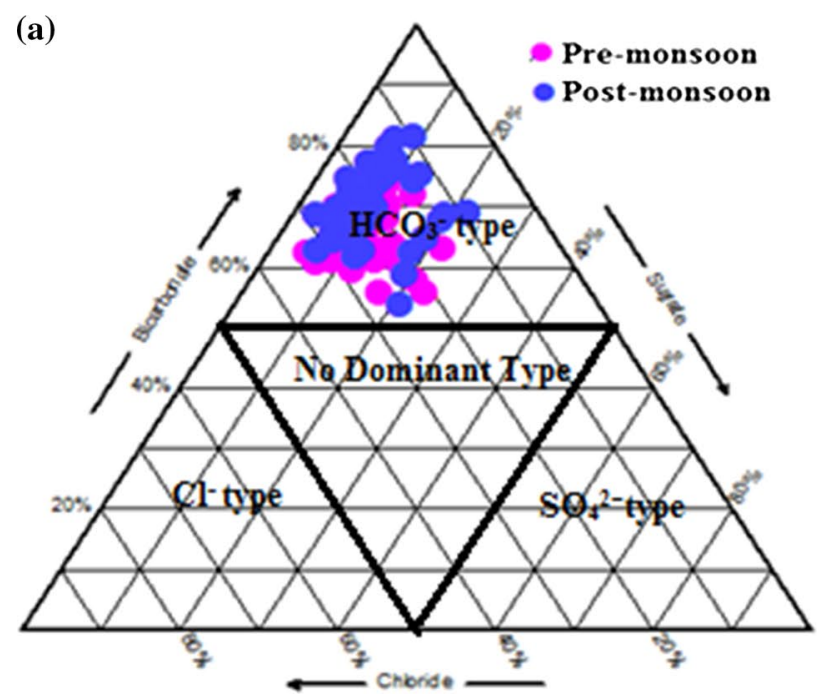

occurring in groundwater system and can indicate mixing of different water types, ion exchange and reverse ion exchange process (Aly et al. 2015). The diagram is a composite plot consisting of two ternary diagrams where the cations $\left(\mathrm{Na}^{+}+\mathrm{K}^{+}, \mathrm{Ca}^{2+}, \mathrm{Mg}^{2+}\right)$ of interest are plotted against the anions $\left(\mathrm{Cl}^{-}, \mathrm{HCO}_{3}{ }^{-}, \mathrm{SO}_{4}{ }^{2-}\right)$ of interest; sides form a binary plot of total cation versus total anion concentrations; expanded version includes total dissolved solids $(\mathrm{mg} / \mathrm{L})$ and $\mathrm{pH}$ data added to the sides of the binary plot to allow further comparisons. Durov diagram was used to evaluate the hydrogeochemical process in the groundwater of the study area and is shown in Fig. 7. The cation triangle displays that most of the groundwater samples are showing no dominant type during both seasons, respectively. The majority of the water samples are falling in the field 5 which indicates mixing process of two or more different facies during both seasons, respectively, while some samples are falling in filed 6 that indicates reverse ion exchange process. On the anion triangle, most of the groundwater samples are showing $\mathrm{HCO}_{3}{ }^{-}$type indicates that the groundwaters fall in the region of carbonate weathering during both seasons, respectively. In general, weathering of rocks and ion exchange process are mainly controlling the groundwater chemistry of the study area.

\section{Estimation of GIS-based WQI}

Water quality index is one of the most effective tools to communicate information on the quality of any water body. The WQI was computed to assess the quality of groundwater of Bokaro district for the pre-and post-monsoon seasons. The computed WQI values of groundwater samples ranged from 54.73 to 228.02 (avg. 125.51) in the pre-monsoon season and

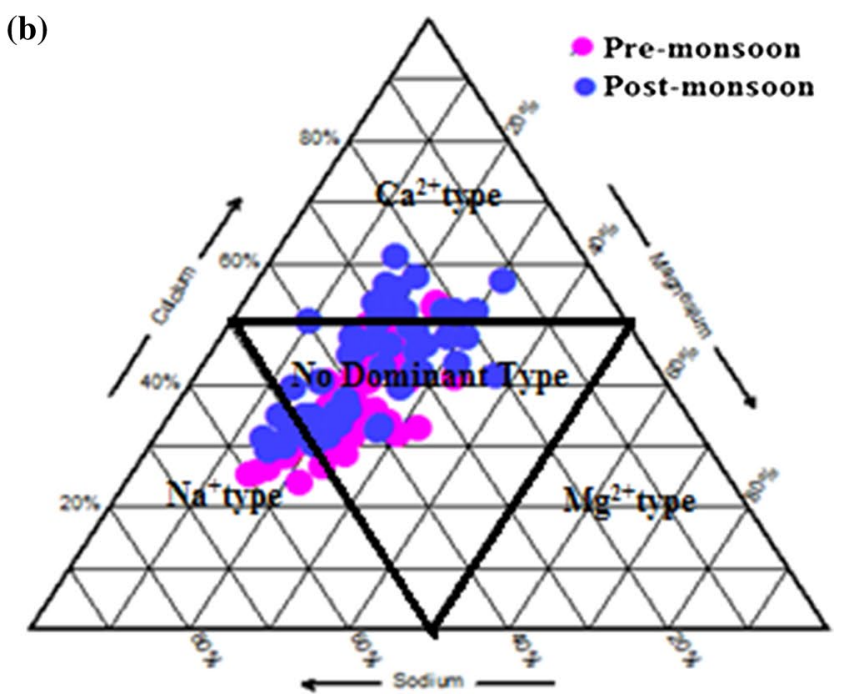

Fig. 6 Ternary anion (a)-cation (b) diagram of the groundwater samples 
Fig. 7 Durov diagram for Bokaro district groundwater samples

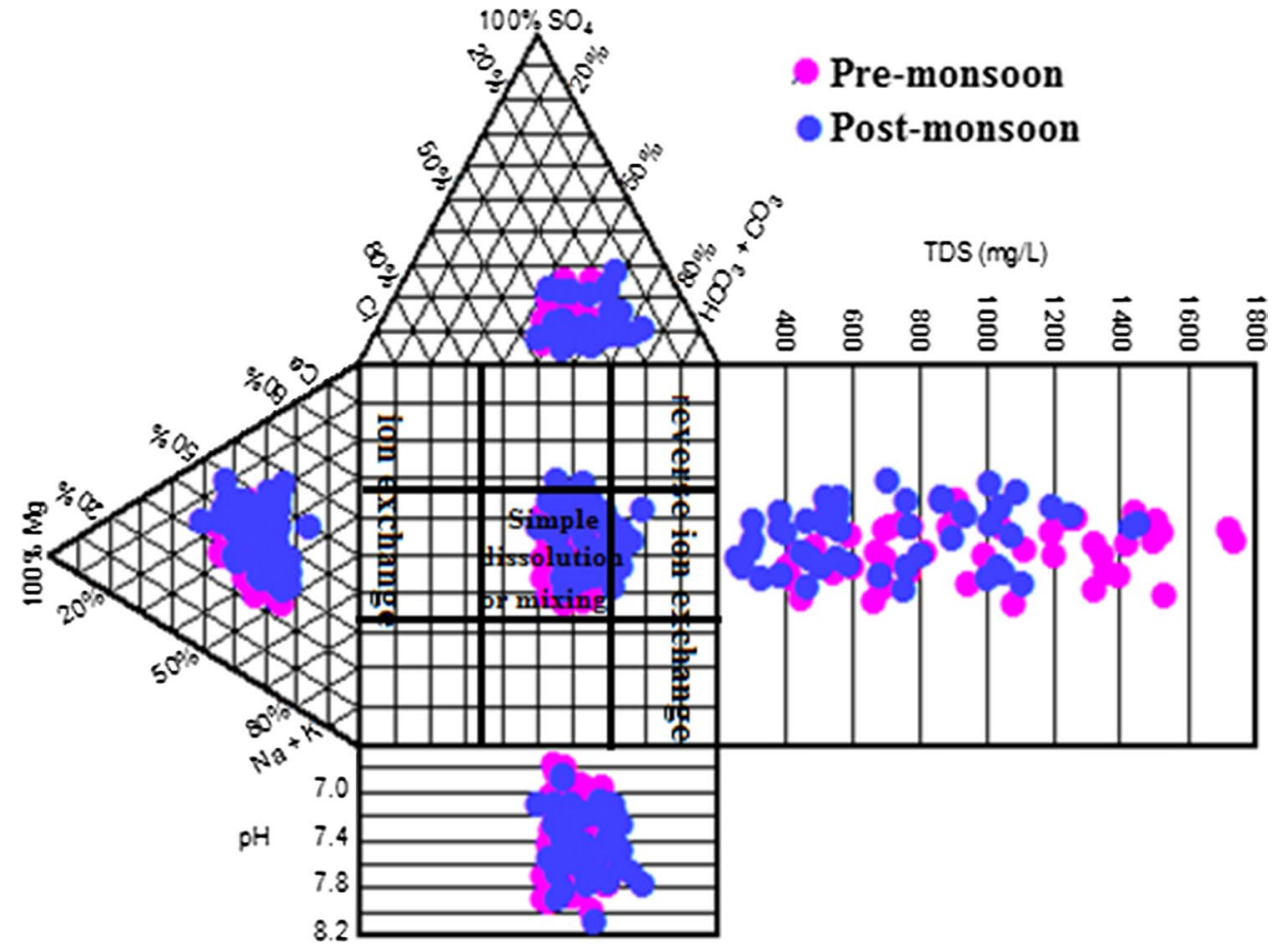

from 38.85 to 185.61 (avg. 95.11) in the post-monsoon season, respectively. The highest WQI value was calculated for the samples collected from the Siwandih, Hazari and Bhawanipur sampling locations (Table 4). The higher WQI values in the groundwater of the Bokaro district were found in the premonsoon season as compared to the post-monsoon season as shown in Fig. 8. The higher values of WQI in the study area were observed due to the higher concentrations of TDS, $\mathrm{F}^{-}$, $\mathrm{Cl}^{-}, \mathrm{NO}_{3}{ }^{-}$and $\mathrm{SO}_{4}{ }^{2-}$ in the groundwater samples during both the seasons, respectively. The WQI values in the groundwater samples may be attributed due to the natural and anthropogenic activities of the study area. However, lower values of WQI in the post-monsoon season of the study area indicate a dilution affect. Among all of the groundwater samples, the percentage (\%) of WQI categories was good (43. 13\%), poor $(50.98 \%)$ and very poor $(5.89 \%)$ in the pre-monsoon season (Table 5 and Fig. 8a). However, in the post-monsoon season the percentage (\%) of WQI categories is excellent $(11.77 \%)$, good (43. $13 \%)$ and poor $(45.10 \%)$ of the groundwater samples (Table 5 and Fig. 8b). These results indicate the groundwater is moderately polluted and not suitable for direct drinking uses.

\section{Conclusion}

The spatial and temporal analysis of physicochemical parameters of the groundwater of Bokaro district was assessed to determine its suitability for drinking purpose.
$\mathrm{pH}$ values of the groundwater were slightly acidic to slightly alkaline nature during both the seasons. Concentrations of TDS, TH, $\mathrm{Ca}^{2+}, \mathrm{Mg}^{2+}, \mathrm{HCO}_{3}{ }^{-}, \mathrm{NO}_{3}{ }^{-}$and $\mathrm{F}^{-}$exceeded permissible limits of drinking water standards prescribed by the WHO (2004) and BIS (2012) in the study area during both seasons. The other parameters $\left(\mathrm{Cl}^{-}, \mathrm{SO}_{4}{ }^{2-}\right.$, and $\left.\mathrm{Na}^{+}\right)$were within the limits during both seasons, respectively. The higher concentration of TDS in the study area may be due to the presence of higher concentration of $\mathrm{Ca}^{2+}, \mathrm{Mg}^{2+} \mathrm{HCO}_{3}{ }^{-}, \mathrm{F}^{-}$and $\mathrm{NO}_{3}{ }^{-}$. The lower concentrations of TDS, TH, $\mathrm{Ca}^{2+}, \mathrm{Mg}^{2+} \mathrm{HCO}_{3}^{-}, \mathrm{F}^{-}$and $\mathrm{NO}_{3}{ }^{-}$of the groundwater samples during the post-monsoon season as compared to the pre-monsoon season indicate that monsoon plays a significant role for decreasing the concentrations of these parameters. The hydrochemical analysis of studied groundwater samples revealed that most of the groundwater samples belong to $\mathrm{HCO}_{3}{ }^{-}$type of anions facies and some samples $\mathrm{Ca}^{2+}$ and $\mathrm{Na}^{+}$type, and remaining samples are no dominant type of cation facies. The GIS-based WQI results showed that $50.98 \%$ and $45.10 \%$ of the groundwater samples were found as a poor category in the pre- and post-monsoon seasons and not suitable for drinking use. The results of present study revealed that the chemistry of groundwater of the study area was controlled by the rock weathering, ion exchange processes and anthropogenic activities. Proper water resources management plans are requiring in the study for managing the groundwater resources problems. 
Table 4 Water quality index values for the groundwater during pre-and post-monsoon season of the Bokaro district

\begin{tabular}{|c|c|c|c|c|c|}
\hline S. no. & Location & $\begin{array}{l}\text { WQI values } \\
\text { Pre-monsoon }\end{array}$ & Description & $\begin{array}{l}\text { WQI values } \\
\text { Pre-monsoon }\end{array}$ & Description \\
\hline Gw1 & Badhadih & 118.02 & Poor water & 71.36 & Good water \\
\hline Gw2 & Jharna & 79.81 & Good water & 63.11 & Good water \\
\hline Gw3 & Chinigariya & 109.34 & Poor water & 74.27 & Good water \\
\hline Gw4 & Bermo & 85.23 & Good water & 65.78 & Good water \\
\hline Gw5 & Bijulia & 133.69 & Poor water & 74.98 & Good water \\
\hline Gw6 & Parbatpur & 179.50 & Poor water & 112.00 & Poor water \\
\hline Gw7 & Kudwadih & 185.74 & Poor water & 124.05 & Poor water \\
\hline Gw8 & Dantu & 90.28 & Good water & 53.29 & Good water \\
\hline Gw9 & Kashi Jharia & 102.34 & Poor water & 82.15 & Good water \\
\hline Gw10 & Dantu & 167.79 & Poor water & 127.54 & Poor water \\
\hline Gw11 & Jainamore & 110.37 & Poor water & 89.05 & Good water \\
\hline Gw12 & Dhandaber & 80.25 & Good water & 56.79 & Good water \\
\hline Gw13 & Siwandih & 214.86 & Very poor water & 183.02 & Poor water \\
\hline Gw14 & Gudkutarh & 186.34 & Poor water & 163.61 & Poor water \\
\hline Gw15 & Santhaldih & 59.39 & Good water & 41.47 & Excellent water \\
\hline Gw16 & Pupunki & 69.94 & Good water & 45.89 & Excellent water \\
\hline Gw17 & Telgaria more & 196.16 & Poor water & 136.86 & Poor water \\
\hline Gw18 & Hazari & 204.61 & Very poor water & 155.42 & Poor water \\
\hline Gw19 & Kalyanpur (Baru) & 129.31 & Poor water & 103.42 & Poor water \\
\hline Gw20 & Mamkudar & 91.38 & Good water & 62.85 & Good water \\
\hline Gw21 & Laghla & 172.48 & Poor water & 129.21 & Poor water \\
\hline Gw22 & Bhawanipur & 228.16 & Very poor water & 185.61 & Poor water \\
\hline Gw23 & Chadankiyari & 174.21 & Poor water & 145.21 & Poor water \\
\hline Gw24 & Khasmahal & 58.40 & Good water & 42.57 & Excellent water \\
\hline Gw25 & Sitanalah & 178.13 & Poor water & 138.05 & Poor water \\
\hline Gw26 & Pidrajora & 159.16 & Poor water & 125.16 & Poor water \\
\hline Gw27 & Tulbul & 148.57 & Poor water & 102.20 & Poor water \\
\hline $\mathrm{Gw} 28$ & Peterwar & 169.67 & Poor water & 138.25 & Poor water \\
\hline Gw29 & Pindrajora & 196.06 & Poor water & 160.58 & Poor water \\
\hline Gw30 & Gomia & 119.89 & Poor water & 87.99 & Good water \\
\hline Gw31 & Jainamore & 98.25 & Good water & 79.49 & Good water \\
\hline Gw32 & Nerki & 77.84 & Good water & 55.57 & Good water \\
\hline Gw33 & Balidih & 147.64 & Poor water & 120.19 & Poor water \\
\hline Gw34 & Telgaria more & 168.72 & Poor water & 135.68 & Poor water \\
\hline Gw35 & Pichri & 61.23 & Good water & 42.37 & Excellent water \\
\hline Gw36 & Chapri & 128.92 & Poor water & 103.69 & Poor water \\
\hline Gw37 & Baladih & 123.81 & Poor water & 104.58 & Poor water \\
\hline Gw38 & Phusro & 93.27 & Good water & 79.48 & Good water \\
\hline Gw39 & Khadudih & 73.52 & Good water & 51.12 & Good water \\
\hline Gw40 & Bodro & 85.61 & Good water & 63.82 & Good water \\
\hline Gw41 & Lalpania & 97.64 & Good water & 75.34 & Good water \\
\hline Gw42 & Khutari & 54.73 & Good water & 38.85 & Excellent water \\
\hline Gw43 & Nawadih & 95.77 & Good water & 68.35 & Good water \\
\hline Gw44 & Siwandih & 158.34 & Poor water & 119.97 & Poor water \\
\hline Gw45 & Laghla & 69.66 & Good water & 47.07 & Excellent water \\
\hline Gw46 & Peterwar & 87.09 & Good water & 69.47 & Good water \\
\hline Gw47 & Bazar Sammittee & 88.18 & Good water & 73.33 & Good water \\
\hline Gw48 & Sitanalah & 183.54 & Poor water & 139.51 & Poor water \\
\hline Gw49 & Badhnadih & 102.51 & Poor water & 78.49 & Good water \\
\hline Gw50 & Parbatpur & 90.68 & Good water & 70.83 & Good water \\
\hline Gw51 & Laheria tanr & 83.56 & Good water & 57.52 & Good water \\
\hline
\end{tabular}




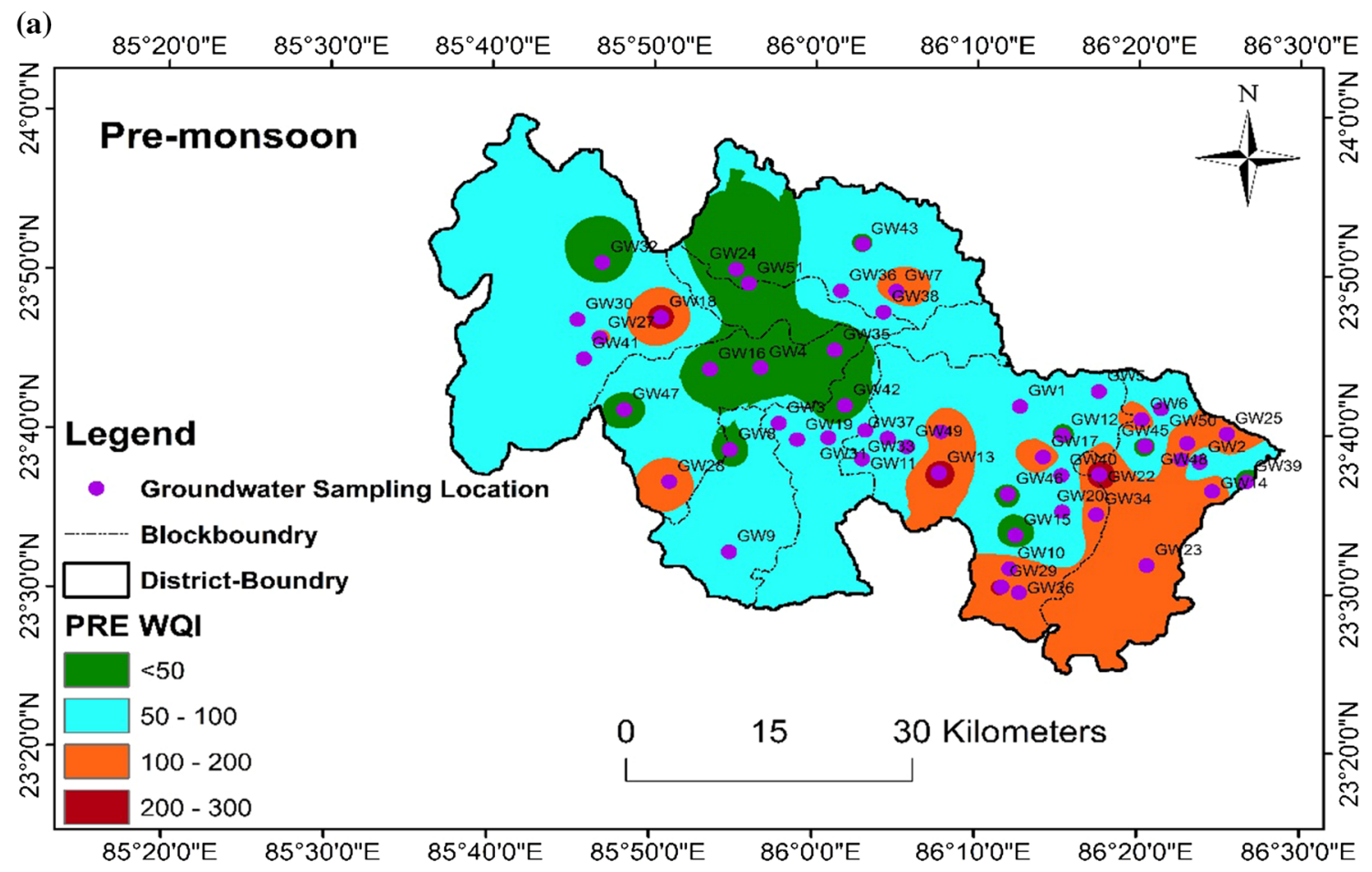

(b) $85^{\circ} 20^{\prime} 0^{\prime \prime} \mathrm{E} \quad 85^{\circ} 30^{\prime} \mathrm{O}^{\prime \prime} \mathrm{E} \quad 85^{\circ} 40^{\prime} \mathrm{O}^{\prime \prime} \mathrm{E} \quad 85^{\circ} 50^{\prime} 0^{\prime \prime} \mathrm{E} \quad 86^{\circ} 0^{\prime} \mathrm{O}^{\prime \prime} \mathrm{E} \quad 86^{\circ} 10^{\circ} 0^{\prime \prime} \mathrm{E} \quad 86^{\circ} 20^{\prime} \mathrm{O}^{\prime \prime} \mathrm{E} \quad 86^{\circ} 30^{\prime} \mathrm{O}^{\prime \prime} \mathrm{E}$

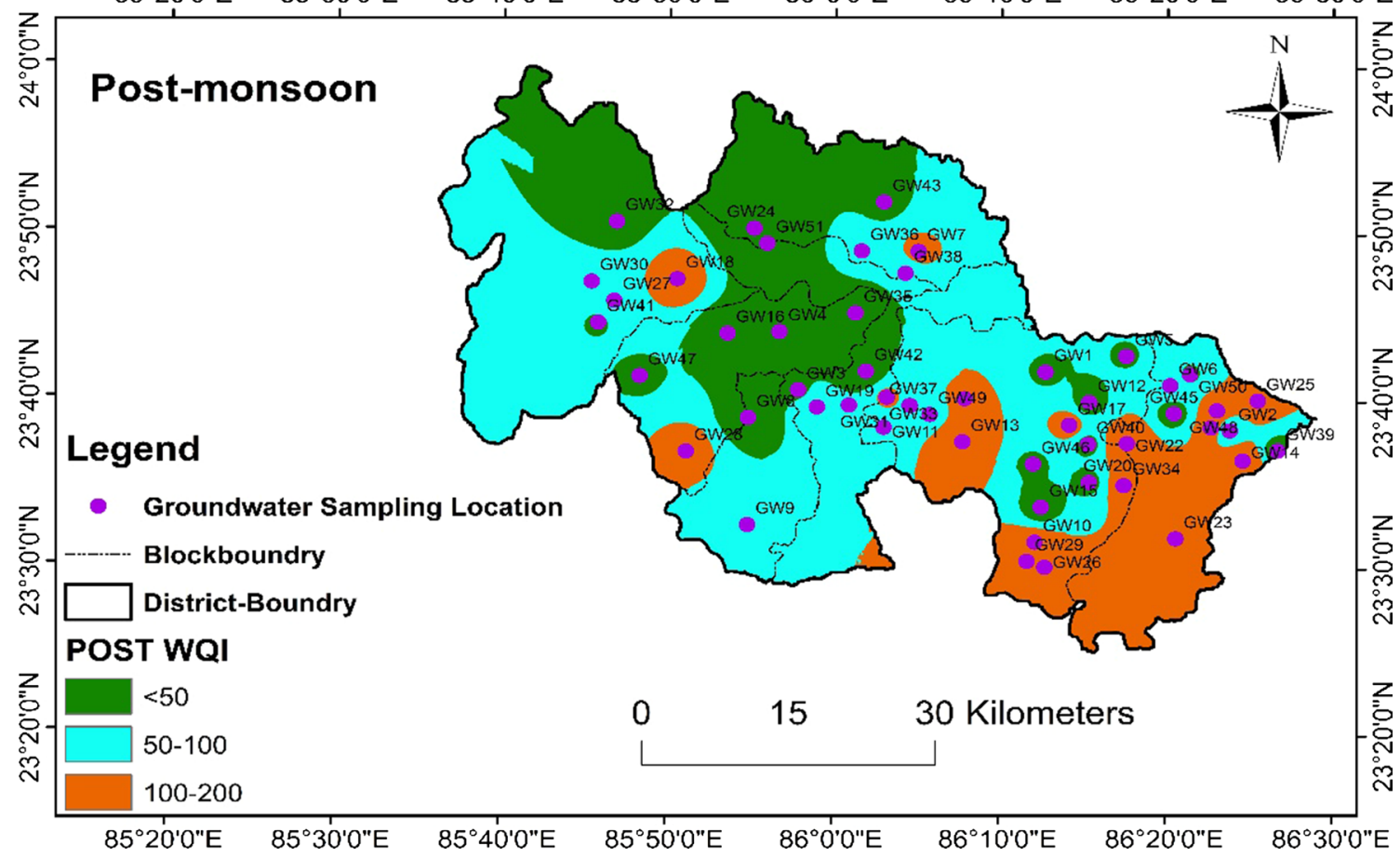

Fig. 8 Spatial distribution of WQI values in the groundwater of the Bokaro district 
Table 5 Classification of water based on WQI in percentage

\begin{tabular}{llll}
\hline WQI range & Type of water & $\begin{array}{l}\text { \% of samples in } \\
\text { the pre-monsoon }\end{array}$ & $\begin{array}{l}\text { \% of samples } \\
\text { in the post- } \\
\text { monsoon }\end{array}$ \\
\hline$<50$ & Excellent water & & $11.77 \%(6)$ \\
$50-100$ & Goodwater & $43.13 \%(22)$ & $43.13 \%(22)$ \\
$100-200$ & Poor water & $50.98 \%(26)$ & $45.10 \%(23)$ \\
$200-300$ & Very poor water & $5.89 \%(3)$ & - \\
$>300$ & $\begin{array}{l}\text { Water unsuit- } \\
\text { able for drinking } \\
\text { purpose }\end{array}$ & - \\
& & \\
\hline
\end{tabular}

Acknowledgements Authors thank the Head of Department of the Department of Environmental Science and Engineering, Indian Institute of Technology (Indian School of mines), Dhanbad, India, for providing research laboratory for analytical work and permission to publish this research article. We are grateful to the Editors and anonymous reviewers for their valuable suggestions.

Open Access This article is distributed under the terms of the Creative Commons Attribution 4.0 International License (http://creativeco mmons.org/licenses/by/4.0/), which permits unrestricted use, distribution, and reproduction in any medium, provided you give appropriate credit to the original author(s) and the source, provide a link to the Creative Commons license, and indicate if changes were made.

\section{References}

Aly AA, Al-Omran AM, Alharby MM (2015) The water quality index and hydrochemical characterization of groundwater resources in Hafar Albatin, Saudi Arabia. Arab J Geosci 8:4177-4190

APHA (2012) Standard methods for the examination of water and waste-water. American Public Health Association, Washington

Appelo CAJ, Postma D (1996) Geochemistry, groundwater and pollution. AABalkema Publication, Rotterdam

BIS (Bureau of Indian Standards) 10500 (2012) Indian Standard Drinking Water Specification

Brown RM, McClelland NI, Deininger RA, Tozer RG (1970) A water quality index: do we dare? Water Sewage Works 117:339-343

Canter LW (1997) Nitrates in groundwater. Lewis Publisher, New York

Central Ground Water Board (2013) Ministry of Water Resources (Govt. of India) State Unit Office, Ranchi Mid-Eastern Region Patna

Chandra S, Singh PK, Tiwari AK, Panigrahy B, Kumar A (2015) Evaluation of hydrogeological factor and their relationship with seasonal water table fluctuation in Dhanbad district, Jharkhand, India. ISH J Hydraul Eng 21:193-206

Chatterjee R, Tarafder G, Paul S (2010) Groundwater quality assessment of Dhanbad district, Jharkhand, India. Bull Eng Geol Environ 69:137-141

Chauhan A, Pawar M, Lone SA (2010) Water quality status of Golden Key lake in clement town, Dehradun, Uttarakhand. J Am Sci 6:459-464

Durov SA (1948) Natural waters and graphic representation of their composition. Dokl Akad Nauk SSSR 59:87-90

Horton RK (1965) An index number system for rating water quality. J Water Pollut Control Fed 37:300-306
Jasmin I, Mallikarjuna P (2014) physicochemical quality evaluation of groundwater and development of drinking water quality index for Araniar River Basin, Tamil Nadu, India. Environ Monit Assess 186:935-948

Jeong CH (2001) Effect of land use and urbanization on hydrochemistry and contamination of groundwater from Taejon groundwater sample, Korea. J Hydrol 253:194-210

Latha PS, Rao KN (2012) An integrated approach to assess the quality of groundwater in a coastal aquifer of Andhra Pradesh, India. Environ Earth Sci 66:2143-2169

Milovanovic M (2007) Water quality assessment and determination of pollution sources along the Axios/Vardar River, Southeastern Europe. Desalination 213:159-173

Mishra PC, Patel RK (2001) Study of the pollution load in the drinking water of Rairangpur, a small tribal dominated town of North Orissa. Ind J Environ Ecoplan 5:293-298

Mitra BK, Sasaki C, Keijirou E (2006) Spatial and temporal variation of ground water quality in sand dune groundwater sample of Aomori prefecture in Japan. In: 2006 ASAE annual meeting, ASABE, $p 1$

Nickson RT, McArthur JM, Shrestha B, Kyaw-Myint TO, Lowry D (2005) Arsenic and other drinking water quality issues, Muzaffargarh District, Pakistan. Appl Geochem 20:55-68

Ramakrishnaiah CR, Sadashivaiah C, Ranganna G (2009) Assessment of water quality index for the groundwater in Tumkur Taluk, Karnataka State, India. J Chem 6:523-530

Sarkar BC, Mahanta BN, Saikia K, Paul PR, Singh G (2007) Geoenvironmental quality assessment in Jharia coalfield, India, using multivariate statistics and geographic information system. Environ Geol 51:1177

Satapathy I, Syed TH (2015) Characterization of groundwater potential and artificial recharge sites in Bokaro district, Jharkhand (India), using remote sensing and GIS-based techniques. Environ Earth Sci 74:4215-4232

Singh AK, Hasnain SI (1999) Environmental geochemistry of Damodar River basin, east coast of India. Environ Geol 37:124-136

Singh AK, Mondal GC, Singh PK, Singh S, Singh TB, Tewary BK (2005) Hydrochemistry of reservoirs of Damodar River basin, India: weathering processes and water quality assessment. Environ Geol 8:1014-1028

Singh AK, Mahato MK, Neogi B, Mondal GC, Singh TB (2011) Hydrogeochemistry, elemental flux, and quality assessment of mine water in the Pootkee-Balihari mining area, Jharia coalfield, India. Mine Water Environ 30:197

Singh AK, Raj B, Tiwari AK, Mahato MK (2013) Evaluation of hydrogeochemical processes and groundwater quality in the Jhansi district of Bundelkhand region, India. Environ Earth Sci 70:1225-1247

Štambuk-Giljanović N (1999) Water quality evaluation by index in Dalmatia. Water Resour 33:3423-3440

Tiwari TN, Mishra MA (1985) A preliminary assignment of water quality index of major Indian rivers. Indian J Environ Prot 5:276-279

Tiwari AK, Singh AK (2014) Hydrogeochemical investigation and groundwater quality assessment of Pratapgarh District, Uttar Pradesh. J Geol Soc India 83(3):329-343

Tiwari AK, Singh PK, Mahato MK (2016) Environmental geochemistry and a quality assessment of mine water of the West Bokaro coalfield, India. Mine Water Environ 35:525-535

Tiwari AK, Singh AK, Mahato MK (2017) Assessment of groundwater quality of Pratapgarh district in India for suitability of drinking purpose using water quality index (WQI) and GIS technique. DOI, Sustain Water Resour Manag. https://doi.org/10.1007/s4089 9-017-0144-1

Tiwary RK (2001) Environmental impact of coal mining on water regime and its management. Water Air Soil Pollut 132:185-199

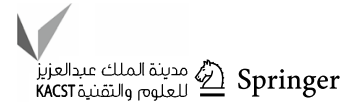


Vasanthavigar M, Srinivasamoorthy K, Vijayaragavan K, Ganthi RR, Chidambaram S, Anandhan P, Vasudevan S (2010) Application of water quality index for groundwater quality assessment: Thirumanimuttar sub-basin, Tamilnadu, India. Environ Monit Assess 171:595-609

WHO (2004) Guidelines for drinking water quality: training pack. WHO, Geneva

World Bank (1998) India-Water resources management sector review: groundwater regulation and management report world development sources, WDS 1998-3. World Bank, Washington
Yadav KK, Gupta N, Kumar V, Sharma S, Arya S (2015) Water quality assessment of Pahuj River using water quality index at Unnao Balaji, MP, India. Int J Sci Basic Appl Res 19:241-250

Zilberbrand M, Rosenthal E, Shachnai E (2001) Impact of urbanization on the hydrochemical evolution of groundwater and on unsaturated-zone gas composition in the coastal city of Tel Aviv, Israel. J Contam Hydrol 50:175-208

Publisher's Note Springer Nature remains neutral with regard to jurisdictional claims in published maps and institutional affiliations. 